\title{
Evaluation of a Reduced Copper Spraying Program to Control Bacterial Blight of Walnut
}

\author{
Antònia Ninot, Research Agronomist, and Neus Aletà, Research Agronomist, Departament d'Arboricultura \\ Mediterrània, IRTA, Centre de Mas Bové, 43280 Reus, Spain; and Concepció Moragrega, Associate Professor, and \\ Emilio Montesinos, Professor, Institute of Food and Agricultural Technology-CeRTA, University of Girona, 17003
} Girona, Spain

\begin{abstract}
Ninot, A., Aletà, N., Moragrega, C., and Montesinos, E. 2002. Evaluation of a reduced copper spraying program to control bacterial blight of walnut. Plant Dis. 86:583-587.

Walnut blight, caused by Xanthomonas arboricola pv. juglandis, is currently controlled in western Europe through a standard schedule of seven applications of sprayed copper from bud break until harvest. A reduced spray schedule, with the last four applications omitted, was compared to the standard program in experimental plots for 3 years. Bacterial population levels in the spring were not significantly different between trees subjected to reduced sprays and those subjected to the standard schedule, but in summer they were higher in the trees that received fewer sprays compared with the standard program. However, disease control on nuts was similar or even better with the reduced spraying program than with the standard program, with the additional economic benefit of four fewer copper applications. After 3 years of using the reduced spray program, the amount of copper accumulated in the soil was significantly lower (about half) than that found in the soil where the standard spray program was implemented.
\end{abstract}

Additional keywords: Bordeaux mixture, Juglans regia

Bacterial blight of Persian (English) walnut (Juglans regia L.), caused by Xanthomonas campestris (Pammel) Dowson pv. juglandis (Pierce) Dye $=$ Xanthomonas arboricola pv. juglandis (Pierce) Vauterin, Hoste, Kersters \& Swings, $(25,26)$, is a disease of economic importance in all walnut-producing areas, and the severity of outbreaks depends to a great extent on spring weather conditions. The disease is currently an important limiting factor in many walnut orchards (14).

All new walnut tissue is susceptible to infection and necrosis can occur in catkins, female flowers, leaves, fruit, and green shoots. Catkin infection begins in individual florets, which turn black, die, and shrivel. Infected flowers usually shrivel and drop from the tree. Symptoms on leaves begin as small dark-brown specks surrounded by a yellowish halo, which lead to more extensive necrosis in advanced stages. Infected leaves remain on the tree

Corresponding author: A. Ninot

E-mail: antonia.ninot@irta.es

This project was started in the framework of a European contract between IRTA and the Centre Techniques des Fruits et Légumes (CTIFL-France) in 1991 and 1997 and supported by Spanish public funding from the Instituto Nacional de Investigaciones Agrarias (INIA).

Accepted for publication 17 January 2002.

Publication no. D-2002-0329-04R

(C) 2002 The American Phytopathological Society to become sources of new infection. Earlyinfected nutlets develop a dark lesion and most of them drop off the tree, whereas mature nuts can develop lesions anywhere on the hull surface and may remain on the tree. Mesocarp lesions begin as small water-soaked spots, which later darken. The internal kernel usually shrivels, making it unmarketable or decreasing fruit quality (3). Host susceptibility differs not only among cultivars $(15,27)$, but also among plant organs within the same cultivar $(2,19)$. The pathogen needs free moisture to multiply and cause infection, and free water in the orchard is the main vector for the spread of bacteria (13).

Disease control is achieved through preventive spraying with copper bactericides, but efficacy is often very limited $(7,11,21)$. Copper-resistant strains of $X$. arboricola pv. juglandis have been isolated from walnut orchards where intensive copper spraying was used for disease control $(7,11)$. Applications of intensive copper treatments over many years in commercial orchards have resulted in the accumulation of copper in soils, with subsequent negative environmental impact. Excess copper in the soil can alter plants' ability to metabolize nitrogen (6). In walnut trees, high levels of copper can have undesired effects on the soil, disturb tree performance, and predispose fruit to necrosis (19). High levels of copper also have been reported to be toxic to grapefruit roots because copper interferes with uptake of iron and other nutrients, especially in acidic soils (23).
Consequently, a reduction in copper applications in orchards is needed. The fullseason program is still used in western Europe, whereas in California only the early-season program is used $(4,11,18)$. However, there is no information comparing the efficacy of full-season (standard) and early-season (reduced) treatment programs in control of bacterial blight of walnut.

The purpose of this study was to evaluate the efficacy of a reduced copper spray program compared with the standard copper application program used for walnut blight control in commercial orchards.

\section{MATERIALS AND METHODS}

Plant material and experimental plot characteristics. A field plot of 144 trees of cv. Serr grafted onto J. regia located in Reus, Catalonia, Spain, was used. Trees were 9 years old and arranged in 12 rows of 12 trees per row with a tree density of 238 trees/ha. Trees were irrigated using a microsprinkler system and water was supplied according to evapotranspiration data collected in the same experimental plot. Soil in the plot was alkaline and had a clay-loam texture. Environmental parameters were recorded during the field trials (from April to August) in 1996, 1997 and 1998 by means of an automatic weather station located at the Research Center Mas Bové, placed $3 \mathrm{~km}$ from the trial orchard. Weather parameters were monitored with a CR10X datalogger (Campbell Scientific Ltd., Leicester, UK) connected to combined temperature-relative humidity (model HMP35AC) and rainfall (model ARG100) electronic sensors. Temperature and relative humidity were measured every $10 \mathrm{~min}$ and rainfall every $20 \mathrm{~s}$. Mean temperature, relative humidity, and total rainfall were recorded by the datalogger at hourly intervals. From these data, monthly mean, minimum, and maximum temperature; mean relative humidity; and total rainfall were calculated.

Treatments and experimental design. Bordeaux mixture (20\% metallic copper) was applied with a handgun sprayer to the point of runoff at a rate of $2 \mathrm{~kg}$ of metallic copper/ha ( $2 \mathrm{~g} /$ liter). In the autumn before the experiment began, the plot was sprayed at a rate of $2.5 \mathrm{~kg}$ metallic copper/ha $(2.5$ $\mathrm{g} /$ liter). The treatments evaluated were two spray programs and an untreated control. 
The standard program consisted of seven sprays; whereas, in the reduced program, there were only three sprays. In both programs, the first copper spray was applied in the $\mathrm{Cf}$ (bud break) phenological stage, the second in the Ff2 (full female blooming) phenological stage, and the third in the Gf (fruit set) phenological stage (9). The

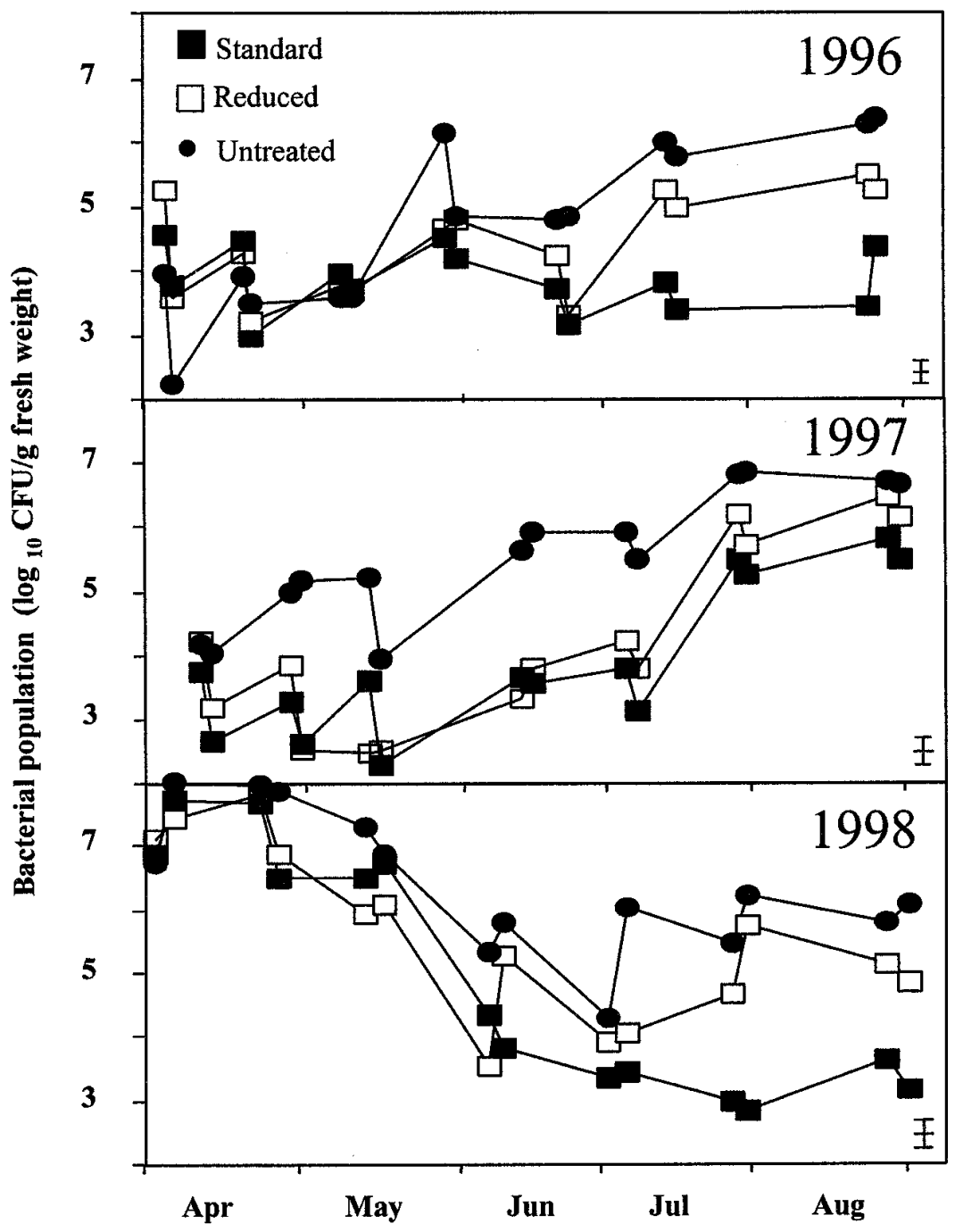

Fig. 1. Dynamics of population levels of Xanthomonas arboricola pv. juglandis on walnut buds or leaflets during 1996, 1997, and 1998 on trees treated according to the standard or reduced copper spray programs, compared with the untreated control. The standard program consisted of a total of seven copper sprays, three of which were applied at bud break, full female blooming, and fruit set, and the remaining four at about 3week intervals from June to August. The reduced program consisted of three copper sprays applied at bud break, full female blooming, and fruit set. Data values are the means of bacterial population levels in buds or leaflets in five replications with two trees per replication. Error bars placed on the right bottom corner of each panel correspond to the mean standard error of all bacterial population values. last four sprays in the standard program were applied every 20 to 30 days after the Gf stage (from June to August).

The experimental design was a randomized complete block of three treatments (one untreated control and two programs) and five replications of two trees per replication. All sprays took place on the same tree during the 3 years of the study. The field trial was performed during three consecutive years (1996, 1997, and 1998). To prevent interference between treatments, each plot (replication) was surrounded by a row of guard trees.

Measurement of epiphytic populations of $X$. arboricola pv. juglandis. Ten buds or leaves were sampled from the two trees of each treatment replication the day before copper was applied and again 2 days later. Epiphytic populations of $X$. arboricola pv. juglandis on buds or leaves (depending on the walnut phenological stage) were determined. For each sample, 5 $\mathrm{g}$ of buds or leaves was placed in plastic bags containing $20 \mathrm{ml}$ of sterile distilled water (SDW) with $0.001 \%$ Tween 20 and the mixture was processed for $5 \mathrm{~min}$ in a stomacher homogenizer. Sample extracts were 10 -fold serially diluted six times. In case of samples collected from treated trees, the amount of copper contained in the plant material extracts was sufficiently diluted by this procedure so that it had no significant effect on colony growth. A 100$\mu \mathrm{l}$ aliquot from selected dilutions was spread onto the surface of petri dishes containing yeast extract-dextrose-calcium carbonate (YDC) agar (22). On this medium, $X$. arboricola pv. juglandis produces large, smooth and mucoid, domed, and typically yellow pigmented colonies. After 4 days of incubation in the dark at $25^{\circ} \mathrm{C}$, the colonies were counted and bacterial populations were expressed as CFU per gram of fresh weight of bud or leaf. The analysis was repeated twice for each sample. In preliminary studies, most of these colonies were identified as $X$. arboricola pv. juglandis and they were tested for pathogenicity by inoculating in the laboratory immature nuts of walnuts cv. Chico. Pathogenicity was periodically evaluated

Table 1. Effects of standard and reduced copper spray programs on epiphytic populations of Xanthomonas arboricola pv. juglandis on walnut buds or leaflets in experimental orchard plots during 1996 and 1998

\begin{tabular}{|c|c|c|c|c|c|c|c|}
\hline \multirow[b]{3}{*}{ Treatment $^{\mathrm{z}}$} & \multirow[b]{3}{*}{ No. of applications } & \multicolumn{6}{|c|}{$\log _{10}$ CFU/g fresh weighty } \\
\hline & & \multicolumn{2}{|c|}{1996} & \multicolumn{2}{|c|}{1997} & \multicolumn{2}{|c|}{1998} \\
\hline & & 4 April & 18 August & 11 April & 22 August & 2 April & 31 August \\
\hline Untreated & 0 & $4.0 \mathrm{c}$ & $6.4 \mathrm{a}$ & 4.1 & $6.7 \mathrm{a}$ & 6.7 & $6.1 \mathrm{a}$ \\
\hline Reduced & 3 & a & $b$ & 4.2 & 6 & 7.1 & $4.9 \mathrm{~b}$ \\
\hline Standard & 7 & $4.5 \mathrm{~b}$ & $4.4 \mathrm{c}$ & 3.7 & $5.5 \mathrm{c}$ & 6.9 & $3.2 \mathrm{c}$ \\
\hline \multicolumn{8}{|c|}{$\begin{array}{l}\text { Values are the mean of five plots with two trees per plot. Within each column, values followed by the same letter are not significantly different }(P> \\
0.05) \text { according to the Waller-Duncan } k \text {-ratio } t \text { test. }\end{array}$} \\
\hline \multicolumn{8}{|c|}{$\begin{array}{l}\text { Trees were sprayed to the point of runoff with a handgun sprayer at a rate of } 200 \mathrm{~g} \text { copper/liter. In both programs, the first copper spray was applied a } \\
\text { the Cf (bud break) phenological stage (4 April 1996, } 11 \text { April 1997, and } 3 \text { April } 3 \text { 1998), the second at the Ff2 (full female blooming) phenological stage } \\
\text { (19 April 1996, } 28 \text { April 1997, and } 24 \text { April in 1998), and the third at the Gf (fruit set) phenological stage (8 May 1996, } 13 \text { May } 1997 \text {, and } 15 \text { May } \\
\text { 1998). The last four sprays in the standard program were applied every } 20 \text { to } 30 \text { days after the Gf stage (28 May, } 18 \text { June, } 9 \text { July, and } 16 \text { August } 1996 \text {; } 11 \\
\text { June, } 1 \text { July, } 22 \text { July, and } 20 \text { August 1997; and 9 June, } 7 \text { July, } 28 \text { July, and } 28 \text { August 1998). }\end{array}$} \\
\hline
\end{tabular}


using selected yellow pigmented colonies taken from samples.

Disease assessment. To assess disease on fruit, 50 fruit from each treatment replication were collected on 1 to 3 August and evaluated for blight symptoms. External necrosis of fruit was rated as described by Martins (12). Disease incidence (the percentage of blighted walnuts) and severity (the percentage of necrotic areas on diseased fruit) were calculated following this method. Fruit was assessed only in 1996 and 1998 because there was a major hailstorm on 2 July 1997 and many nuts dropped off the tree or were irreversibly damaged. For disease assessment on leaves, 10 leaves were collected on 21 to 23 August, when leaves were fully developed, at four locations on the north, south, east, and west sections of the tree canopy. Only the third or fourth leaflet from the distal end of the leaf was evaluated for blight symptoms independently by two assessors, for a total of 40 leaflets per treatment. Disease was assessed according to a pictorial scale (8) with six levels of damage: $0=$ healthy, $1=$ yellowish halos without necrosis, $2=$ necrotic specks, $3=$ three necrotic spots or fewer, $4=$ more than three necrotic spots, and $5=$ with large areas of necrosis.

Copper accumulation in the soil. Six soil samples from each treatment, taken by a soil auger at a depth of 0 to $10 \mathrm{~cm}$ from the soil below the tree canopy, were analyzed. Copper concentration was determined at the end of the third year of the experiment using the EPA 3050 method (24). Copper concentration was expressed as milligrams of metallic copper per kilogram of dry soil sample.

Statistical analysis. Data analysis was performed with Statistical Analysis System software (ver. 8.1; SAS Institute, Cary, NC). Epiphytic population data were $\log _{10}$ transformed before analysis. Fruit data (disease incidence and severity) were transformed before analysis using arc$\sin \sqrt{x}$. Data were analyzed by analysis of variance (ANOVA) with the GLM procedure for differences among treatments on epiphytic population size, fruit disease incidence and severity, and soil copper accumulation. Means were separated by the Waller-Duncan $k$-ratio $t$ test. Leaf disease data were compared among treatments using the RANK procedure and means were separated by the Waller-Duncan $k$ ratio $t$ test.

\section{RESULTS}

Effect of copper sprays on population levels of $X$. arboricola pv. juglandis. The dynamics of bacterial population levels during the 3 years of the study are shown in Figure 1 and data comparisons are summarized in Table 1.

In 1996, the experiment started with a significantly different level of $X$. arboricola pv. juglandis among treatments $(F=$
12.07, $P=0.0001)$. In 1997 and 1998, before the first spraying, these levels were not significantly different $(F=1.20, P=$ 0.3138 and $F=1.89, P=0.1663$, respectively).

The dynamics of population levels in the untreated control varied from one year to the next. In 1996 and 1997, population levels were characterized by an increase of 100 to 1,000 times from April to August (4 to 6 or $7 \log _{10} \mathrm{CFU} / \mathrm{g}$ fresh weight). In 1998, population levels decreased from April to May, then increased slightly from June to August. In August, at the end of each year of the experiment, the bacterial population levels in the untreated control were similar for the 3 years studied.

The dynamics of $X$. arboricola pv. juglandis populations were strongly influenced by the weather conditions from April to August in the years of study. Spring and summer in 1996 and 1997 were cooler and more humid than in 1998. In 1996 and 1997 , monthly mean relative humidity was $\geq 70 \%$ and cumulative rainfall was 159.5 and $204.5 \mathrm{~mm}$, respectively. Early spring and summer in 1998 were dry and warm with monthly mean relative humidity $\leq 72 \%$ and cumulative rainfall of $128.1 \mathrm{~mm}$ (Table 2).

At the end of each annual blight season, population levels of $X$. arboricola pv. juglandis were significantly higher in the untreated control than in the trees treated with copper, while the standard program always had the lowest level of epiphytic populations (1996: $F=31.36, P=0.0001$; 1997: $F=16.90, P=0.0001 ; 1998: F=$ 20.90, $P=0.0001)$. These differences were more pronounced from May to August (after the third copper application), particularly in 1996 and 1998 (Fig. 1).

Effect of the copper application schedule on nut and leaflet blight. The effects of the treatment schedules on walnut blight are shown in Tables 3 and 4 . Blight incidence on nuts from untreated trees was lower in 1996 than in 1998, while severity was higher. On leaflets, disease incidence was higher in 1996 and 1997 than in 1998.

In 1996, disease incidence and severity were significantly lower on nuts treated with copper compared with the untreated

Table 2. Monthly mean, minimum and, maximum air temperature (T); mean relative humidity (RH); and rainfall during 1996, 1997, and 1998 walnut vegetative period in Mas Bové Research Center

\begin{tabular}{lccccc}
\hline Year, month & T mean $\left({ }^{\circ} \mathbf{C}\right)$ & $\mathbf{T}$ min $\left({ }^{\circ} \mathbf{C}\right)$ & T $\mathbf{~ m a x}\left({ }^{\circ} \mathbf{C}\right)$ & RH $(\%)$ & Rainfall $(\mathbf{m m})$ \\
\hline 1996 & & & & & \\
April & 13.7 & 8.1 & 19.3 & 74 & 34.6 \\
May & 16.3 & 10.1 & 22.1 & 74 & 65.9 \\
June & 21.1 & 15.0 & 26.9 & 70 & 15.2 \\
July & 23.0 & 16.8 & 29.0 & 69 & 4.5 \\
August & 23.1 & 18.3 & 28.1 & 78 & 39.3 \\
1997 & & & & & \\
April & 14.4 & 8.5 & 20.2 & 76 & 52.5 \\
May & 17.6 & 11.9 & 23.0 & 70 & 22.3 \\
June & 20.7 & 15.4 & 25.9 & 73 & 70.6 \\
July & 22.3 & 16.1 & 28.3 & 72 & 22.1 \\
August & 24.4 & 19.0 & 29.9 & 78 & 37.0 \\
1998 & & & & & \\
April & 14.1 & 8.7 & 19.7 & 65 & 11.5 \\
May & 17.2 & 12.0 & 22.6 & 68 & 50.3 \\
June & 23.7 & 18.9 & 29.1 & 71 & 0.0 \\
July & 24.1 & 16.0 & 29.5 & 67 & 0.5 \\
August & 23.9 & 17.7 & 29.6 & 72 & 66.3 \\
\hline
\end{tabular}

Table 3. Effects of standard and reduced copper spray programs on the incidence and severity of walnut blight on nuts in experimental orchard plots during 1996 and $1998^{\mathrm{y}}$

\begin{tabular}{|c|c|c|c|c|c|}
\hline \multirow[b]{2}{*}{ Treatment $^{\mathrm{z}}$} & \multirow[b]{2}{*}{$\begin{array}{c}\text { No. of } \\
\text { applications }\end{array}$} & \multicolumn{2}{|c|}{1996} & \multicolumn{2}{|c|}{1998} \\
\hline & & $\begin{array}{c}\text { Incidence } \\
(\%)\end{array}$ & $\begin{array}{c}\text { Severity } \\
(\%)\end{array}$ & $\begin{array}{c}\text { Incidence } \\
(\%)\end{array}$ & $\begin{array}{c}\text { Severity } \\
(\%)\end{array}$ \\
\hline Untreated & 0 & $66.0 \mathrm{a}$ & $49.9 \mathrm{a}$ & $81.0 \mathrm{~b}$ & $22.8 \mathrm{a}$ \\
\hline Reduced & 3 & $31.2 \mathrm{~b}$ & $33.7 \mathrm{~b}$ & $71.6 \mathrm{c}$ & $11.4 \mathrm{c}$ \\
\hline Standard & 7 & $28.4 \mathrm{~b}$ & $45.0 \mathrm{a} \mathrm{b}$ & $95.0 \mathrm{a}$ & $15.5 \mathrm{~b}$ \\
\hline
\end{tabular}

y Disease was assessed on 1 August 1996 and 3 August 1998. Values are the mean of five plots with two trees per plot. Within each column, values followed by the same letter are not significantly different $(P>0.05)$ according to the Waller-Duncan $k$-ratio $t$ test.

${ }^{\mathrm{z}}$ Trees were sprayed to the point of runoff with a handgun sprayer at a rate of $200 \mathrm{~g}$ copper/liter. In both programs, the first copper spray was applied at the Cf (bud break) phenological stage (4 April 1996, 11 April 1997, and 3 April 1998), the second at the Ff2 (full female blooming) phenological stage (19 April 1996, 28 April 1997, and 24 April 1998), and the third at the Gf (fruit set) phenological stage (8 May 1996, 13 May 1997, and 15 May 1998). The last four sprays in the standard program were applied every 20 to 30 days after the Gf stage (28 May, 18 June, 9 July, and 16 August 1996; 11 June, 1 July, 22 July, and 20 August 1997; and 9 June, 7 July, 28 July, and 28 August 1998). 
controls (Table 3). The incidence of nut blight on copper-treated trees was half that on unsprayed trees. In 1998, disease incidence was higher in plots treated with the standard program than in reduced-treatment or untreated plots. Moreover, disease severity also was higher in the standard than in the reduced treatment. The reduced program decreased disease levels in relation to the nontreated control, but the effect was moderate because of the high disease pressure ( $81 \%$ disease incidence). On the other hand, blight incidence on leaflets sprayed with copper was always significantly lower than on untreated controls (Table 4).

Nut disease incidence did not differ significantly between the reduced and standard programs in $1996(F=10.11, P=$ $0.0040)$, but it was lowest in the reduced program in $1998(F=47.15, P=0.0001)$. On leaflets, the reduced spray program provided better disease control than the standard one in $1996(F=114.3, P=$ $0.0001)$ and $1998(F=111.4, P=0.0001)$, but it was less effective than the standard program in $1997(F=89.1, P=0.0001)$.

Copper accumulation in the soil. At the end of the 3-year trial, copper accumulation in the soil from plots treated with the standard program was significantly higher than from plots treated with the reduced spraying program and untreated $(F=4.6, P$ $=0.0268$; Table 5). No differences in soil copper were observed between the reduced program and the untreated control. After 3 years of using the standard schedule, the

Table 4. Effects of standard and reduced copper spray programs on the incidence of walnut blight on leaflets in experimental orchard plots during 1996, 1997, and 1998

\begin{tabular}{lcccc}
\hline & & \multicolumn{3}{c}{ Disease incidence $^{\mathbf{y}}$} \\
\cline { 3 - 5 } Treatment $^{\mathbf{z}}$ & No. of applications & $\mathbf{1 9 9 6}$ & $\mathbf{1 9 9 7}$ & $\mathbf{1 9 9 8}$ \\
\hline Untreated & 0 & $3.9 \mathrm{a}$ & $4.3 \mathrm{a}$ & $2.5 \mathrm{a}$ \\
Reduced & 3 & $3.0 \mathrm{c}$ & $3.7 \mathrm{~b}$ & $1.3 \mathrm{c}$ \\
Standard & 7 & $3.7 \mathrm{~b}$ & $3.4 \mathrm{c}$ & $2.0 \mathrm{~b}$ \\
\hline
\end{tabular}

y Disease was assessed on 23 August 1996, 26 August 1997, and 21 August 1998. Values are the mean of five plots with two trees per plot. Within each column, values followed by the same letter are not significantly different $(P>0.05)$ according to the Waller-Duncan $k$-ratio $t$ test .

${ }^{\mathrm{z}}$ Trees were sprayed to the point of runoff with a handgun sprayer at a rate of $200 \mathrm{~g}$ copper/liter. In both programs, the first copper spray was applied at the $\mathrm{Cf}$ (bud break) phenological stage (4 April 1996, 11 April 1997, and 3 April 1998), the second at the Ff2 (full female blooming) phenological stage (19 April 1996, 28 April 1997, and 24 April 1998), and the third at the Gf (fruit set) phenological stage (8 May 1996, 13 May 1997, and 15 May 1998). The last four sprays in the standard program were applied every 20 to 30 days after the Gf stage (28 May, 18 June, 9 July, and 16 August 1996; 11 June, 1 July, 22 July, and 20 August 1997; and 9 June, 7 July, 28 July, and 28 August 1998).

Table 5. Copper $(\mathrm{Cu})$ levels in the soil of experimental walnut plots after 3 years of copper applications for control of walnut blight

\begin{tabular}{lccc}
\hline Treatment & No. of applications & $\begin{array}{c}\text { Total Cu applied } \\
(\mathbf{k g} / \mathbf{h a})\end{array}$ & $\begin{array}{c}\text { Cu concentration in soil } \\
(\mathbf{m g} / \mathbf{k g})^{\mathbf{z}}\end{array}$ \\
\hline Untreated & 0 & $\ldots$ & $154 \mathrm{~b}$ \\
Reduced & 3 & 18 & $156 \mathrm{~b}$ \\
Standard & 7 & 42 & $242 \mathrm{a}$ \\
\hline
\end{tabular}

${ }^{\mathrm{y}}$ Trees were sprayed to the point of runoff with a handgun sprayer at a rate of $200 \mathrm{~g}$ copper/liter.

${ }^{\mathrm{z}}$ Values are the mean of six replicates per treatment. Within each column, values followed by the same letter are not significantly different $(P>0.05)$ according to the Waller-Duncan $k$-ratio $t$ test. landaceae family $(5,10)$. Copper applied to trees or removed from treated trees may enter the soil ecosystem and have a negative impact on soil microbiota. However, the impact of this problem depends on rainfall levels, the initial amount of copper deposited during the treatment, and the type of formulation (17).

The severity of walnut blight has been related to the frequency and amount of spring rain, the leafing date of the cultivar, the inoculum potential of $X$. arboricola $\mathrm{pv}$. juglandis, and the history of disease in the orchard (18). Most fruit infections are produced in spring from April to May, with no new infections occurring during summer (21). This is related to the fact that the incidence of fruit colonized by $X$. arboricola pv. juglandis decreases from June to early September (21). The bacteria overwinter in buds and the main source of the primary inoculum for the following season are the buds themselves (15). Buds become infected throughout the vegetative season. Our results show that population levels of $X$. arboricola pv. juglandis on buds or leaflets in untreated control trees remained more or less constant during July and August $\left(10^{6}\right.$ to $10^{7} \mathrm{CFU} / \mathrm{g}$ fresh weight). However, population levels were highly variable from one year to the next during spring $\left(10^{4}\right.$ to $10^{8} \mathrm{CFU} / \mathrm{g}$ fresh weight). Therefore, it seems that chemical treatments used to reduce population growth of the pathogen should be concentrated during spring rather than extended into the summer.

Based on the current knowledge of the biological cycle of the pathogen and disease development, we devised a reduced spraying schedule which omitted the last four summer treatments in the standard schedule used for walnut-blight control in commercial orchards. Control of disease on nuts was either not significantly different or was better in the reduced program compared with the standard schedule. Therefore, expanding the protection period by using copper treatments until mid-August did not improve control of walnut blight. Assessment of disease incidence through nut evaluation in untreated trees is difficult due to fruit-drop, which occurs in early spring. This nut fall is smaller in treated trees and most of infected fruit remain on the tree, increasing the disease incidence (e.g., 1998). Blight incidence depends on the amount of initial inoculum; this relationship is more pronounced in years with dry spring seasons (1). In 1998, the initial amount of inoculum was higher than in the other years and spring was drier, showing more blight incidence in that year. Particularly, in 1998 we observed an important fruit-drop in early spring (data not shown) which could not be recorded because of the difficulty of distinguishing blight symptoms from other causes.

We believe that the reduced spray program based on only three fixed copper 
treatments in spring may not be sufficient under certain conditions and in years highly favorable to the disease because of very humid springs or after heavy rain which may limit copper persistence on trees. It has been reported that, in sour cherry trees, copper levels on leaves were reduced by more than half in 1 week after a heavy rain $(40$ to $90 \mathrm{~mm}$ ) to sublethal levels that left trees unprotected (17). In such cases where there is a high risk of disease or low copper persistence, a fourth copper application may be necessary.

Moreover, we observed that, during summer, population levels of $X$. arboricola pv. juglandis were significantly higher in the reduced spray program than in the standard, but were lower than in the untreated control. This may be related to the fact that summer conditions are less suitable to infection in spite of higher levels of the pathogen in the trees following the reduced program. This conclusion agrees with the findings of other reports on the reduced frequency of infection during summer $(18,21)$.

The reduced spray program eliminates more than half (57\%) the copper applications of the standard treatment, even when disease incidence is high (66\% in 1996 and $81 \%$ in 1998). The total amount of copper applied to the orchard was reduced and, as expected, after 3 years of using the reduced spray program, the copper content in the soil was about half that of the plots following the standard spray program. However, the copper levels found in the plots where the reduced spray schedule was used are considered to be toxic for many plants (6).

Finally, this study shows that a reduction in copper use for walnut blight control is possible if spraying is appropriately timed during the vegetative period of the walnut tree and environmental conditions are taken into account. The development of suitable forecasting systems for walnutblight risk assessment is expected to increase the accuracy of treatment timing with an improvement in disease control and reduction of the undesired effects of copper treatments.

\section{ACKNOWLEDGMENTS}

We thank M. Milagros López for help at the beginning of the project and for providing us with a collection of strains of $X$. arboricola pv. juglandis.

\section{LITERATURE CITED}

1. Adaskaveg, J. E., Teviotdale, B., Buchner, R. P., and Olson, B. 1999. Important walnut blight update. Pac. Nut Prod. 4:10, 12-13, 2021.

2. Aletà, N., Ninot, A., Moragrega, C., Llorente, I., and Montesinos, E. 2001. Blight sensitivity of Juglans regia L. Spanish selections. Acta Hortic. 544:353-362.

3. Anonymous. 1982. Integrated Pest Management for Walnuts. University of California, Statewide IPM Project, Division of Agriculture and Natural Resources. University of California Press, Oakland.

4. Buchner, R. P., Adaskaveg, J. E., Olson, W. H., and Lindow, S. E. 2001. Walnut blight (Xanthomonas campestris pv. juglandis) control investigations in Northern California, USA. Acta Hortic. 544:369-378.

5. Cline, S., and Neely, D. 1984. Relationship between juvenile-leaf resistance to anthracnose and the presence of juglone and hydrojuglone glucoside in black walnut. Phytopathology 74:185-188.

6. Delas, J. 1963. La toxicité de cuivre accumulé dans les sols. Agrochimica 7:258-288.

7. Gardan, L., Brault, T., and Germain, E. 1993. Copper resistance of Xanthomonas campestris pv. juglandis in French walnut orchards and its association with conjugative plasmids. Acta Hortic. 311:259-265.

8. Germain, E., Aletà, N., Rouskas, D., GomesPereira, J. A., Monastra, F., Limongelli, F., Ninot, A., and Zakinthinos, G. 1997. Prospections réalisées dans les populations de semis de noyer d'Espagne, de Grèce, d'Italie et du Portugal: caractérisation des populations et description des présélections issues de ces prospections. Options Méditerr. SER. B: Études Recherches 16:9-40.

9. Germain, E., Jalinat, J., and Marchou, M. 1973. Biologie florale du Noyer (Juglans regia L.). Bull. Tech. Inf. 282.

10. Hedin, P. A., Langhans, V. E., and Graves, C. H. Jr. 1979. Identification of juglone in pecan as a possible factor of resistance to Fusicladium effusum. J. Agric. Food Chem. 27:92-94.

11. Lee, Y.-A., Schroth, M. N., Hendson, M., Lindow, S. E., Wang, X.-L., Olson, B., Buchner, R. P., and Teviotdale, B. 1993. Increased toxicity of iron-amended coppercontaining bactericides to the walnut blight pathogen Xanthomonas campestris pv. juglandis. Phytopathology 83:1460-1465.

12. Martins, J. M. S. 1996. A method for measuring the intensity of walnut bacterial blight on fruits. FAO-Nucis Newsl. 5:15-17.

13. Miller, P. W., and Bollen, W. B. 1946. Walnut bacteriosis and its control. Oregon State College, Agric. Exp. Stn. Tech. Bull. 9.

14. Mulrean, E. N., and Schroth, M. N. 1981. Bacterial blight on Persian walnuts. Calif. Agric. 35:11-13.

15. Mulrean, E. N., and Schroth, M. N. 1982. Ecology of Xanthomonas campestris pv. juglandis on Persian (English) walnuts. Phytopathology 72:434-438.

16. Ninot, A., and Aletà, N. 1997. La caracterización de la nuez Europea. Características de las áreas de producción: España. Fruticultura Profesional 84:69-76.

17. Olson, B. D., and Jones, A. L. 1983. Reduction of Pseudomonas syringae pv morsprunorum on Montmorency sour cherry with copper and dynamics of the copper residues. Phytopathology 73:1520-1525.

18. Olson, W. H., Buchner, R. P., Adaskaveg, J. E., and Lindow, S. E. 1997. Walnut blight control in California. Acta Hortic. 442:361365 .

19. Radix, P., Bastien, C., Jay-Allemand, C., Charlot, G., and Seigle-Murandi, F. 1998. The influence of soil nature on polyphenols in walnut tissues. A possible explanation of differences in the expression of walnut blight. Agronomie 18:627-637.

20. Radix, P., and Seigle-Murandi, F. 1993. Hazards of copper accumulation in soils of walnut orchards. Fresenius Environ. Bull. 2:565-569.

21. Radix, P., Seigle-Murandi, F., and Charlot, G. 1994. Walnut blight: development of fruit infection in two orchards. Crop Prot. 13:629631.

22. Schaad, N. W. 1988. Laboratory Guide for Identification of Plant Pathogenic Bacteria. American Phytopathological Society, St. Paul, $\mathrm{MN}$.

23. Timmer, L. W., Zitko, S. E., and Albrigo, L. G. 1998. Split applications of copper fungicides improve control of melanose on grapefruit in Florida. Plant Dis. 82:983-986.

24. United States Environmental Protection Agency (USEPA). Test methods for evaluating solid waste, physical/chemical methods, SW-846. 3rd ed.

25. Vauterin, L., Hoste, B., Kersters, K., and Swings, J. 1995. Reclassification of Xanthomonas. Int. J. Syst. Bacteriol. 45:472489.

26. Vauterin, L., Rademaker, J., and Swings, J. 2000. Synopsis on the taxonomy of the genus Xanthomonas. Phytopathology 90:677-682.

27. Woeste, K. E., McGranahan, G. H., and Schroth, M. N. 1992. Variation among Persian walnuts in response to inoculation with Xanthomonas campestris pv. juglandis. J. Am. Soc. Hortic. Sci. 117:527-531. 